\title{
Isolation and interchange among insular spinner dolphin communities in the South Pacific revealed by individual identification and genetic diversity
}

\author{
Marc Oremus $^{1,2, *}$, M. Michael Poole ${ }^{3}$, Debbie Steel ${ }^{1,4}$, C. Scott Baker ${ }^{1,4}$ \\ ${ }^{1}$ School of Biological Sciences, University of Auckland, Private Bag 92019, Auckland, New Zealand \\ ${ }^{2}$ Centre de Recherches Insulaires et Observatoire de l'Environnement, BP 1013 Papetoai, Moorea, French Polynesia \\ ${ }^{3}$ Marine Mammal Research Program, BP 698 Maharepa, Moorea, French Polynesia \\ ${ }^{4}$ Marine Mammal Program, Hatfield Marine Science Center, Oregon State University, Newport, Oregon 97365, USA
}

\begin{abstract}
Gray's spinner dolphins Stenella longirostris longirostris are found in apparently relatively small and discrete communities around many islands throughout the Pacific. However, the boundaries of these communities, on the scale of a dolphin's lifespan or across generations, are unknown. Here we report a combined demographic and genetic approach to describing the isolation and interchange of insular spinner dolphins among island communities of the Society Archipelago, French Polynesia. Dorsal fin photographs for individual identification and biospy samples for genetic analyses $(\mathrm{n}=154)$ were collected from 6 island communities during 189 small-boat surveys over $3 \mathrm{yr}$. Capture-recapture analyses at Moorea (our primary study site), based on long-term observations of distinctively marked individuals and microsatellite genotypes (12 loci), indicated a local community of about 150 dolphins. This community appeared relatively closed on an intra-generational scale, as confirmed by resightings of individuals across $15 \mathrm{yr}$. Surveys around neighbouring islands indicated the presence of similar distinct communities, likely to follow demographic patterns similar to Moorea, with relatively low levels of interchange between communities. Overall, significant differentiation at both mitochondrial and nuclear levels indicated restricted gene flow among neighbouring communities, although some individual movement was documented. High levels of insular mitochondrial DNA (mDNA) genetic diversity (female long-term effective population size $\left[N_{\mathrm{ef}}\right] \sim 100000$ ) contrasted with demographic characteristics. No evidence of bottlenecks was found in microsatellite allele frequencies or mtDNA haplotypes, discounting the possibility of a recent founder effect. Instead, we suggest that this genetic pattern is the result of metapopulation structure, based on numerous insular communities evolutionarily connected through male and female gene flow.
\end{abstract}

KEY WORDS: Photo-identification $\cdot$ mtDNA $\cdot$ Microsatellite $\cdot$ Abundance $\cdot$ Effective population size $\cdot$ Population structure $\cdot$ Metapopulation

Resale or republication not permitted without written consent of the publisher

\section{INTRODUCTION}

Dolphins are often found in relatively small and apparently discrete coastal or insular communities that are assumed to exhibit genetic exchange with neighbouring communities or larger pelagic populations (e.g. Wells 2003). However, with the exception of a few populations that have been the focus of extensive studies, the social and reproductive boundaries of the communities and the extent of demographic and genetic interchange remain unknown.
Demographic approaches, based principally on photographic documentation of naturally marked individuals (i.e. photo-identification), can provide valuable information on social relationships and local abundance. These methods are limited, however, when assessing large-scale geographic structure and population dynamics that extend across generations. On the other hand, evolutionary approaches are often aimed primarily at estimating population genetic parameters but do not provide a clear distinction between the relative importance of contemporary and historical processes. 
Combining demographic and genetic methods can help overcome the limitations of each (Lande 1988).

Spinner dolphins Stenella longirostris pose an interesting challenge to the description of community structure. The species has a worldwide circumtropical and subtropical distribution (Perrin \& Gilpatrick 1994), within which 4 subspecies have been described based on morphological characters, distribution and habitat preferences (Perrin \& Gilpatrick 1994, Perrin et al. 1999): the eastern spinner $S$. longirostris orientalis, the Central American spinner S. 1. centroamericana, the dwarf spinner $S$. 1. roseiventris and Gray's spinner $S$. 1 . longirostris (Fig. 1a). The distribution of the Central American spinner is limited to waters of the west coast of southern Mexico to the Gulf of Panama, while the dwarf spinner is only found in the Gulf of Thailand and the Timor Sea (Perrin et al. 1999). In the Eastern Trop- ical Pacific (ETP), the eastern spinner and the whitebelly spinner (an apparent hybrid form between $S$. 1 . orientalis and S. 1. longirostris) form large, pelagic, mixed-species aggregations with spotted dolphins $S$. attenuata and yellow-fin tuna Thunnus albacares. Due to this association with tuna, millions of these dolphins have been killed as by-catch in the yellow-fin tuna purse-seine fishery during the last 4 decades (Wade \& Gerrodette 1993). Concerns about the impact of this large-scale dolphin mortality led to numerous studies on various aspects of their biology, including genetic diversity and population structure (e.g. Galver 2002), mating strategies (Perrin \& Mesnick 2003), and abundance (e.g. Wade \& Gerrodette 1993).

In contrast to the pelagic distribution of the eastern and whitebelly spinner, Gray's spinner dolphin is primarily insular in habitat preference (Perrin \&
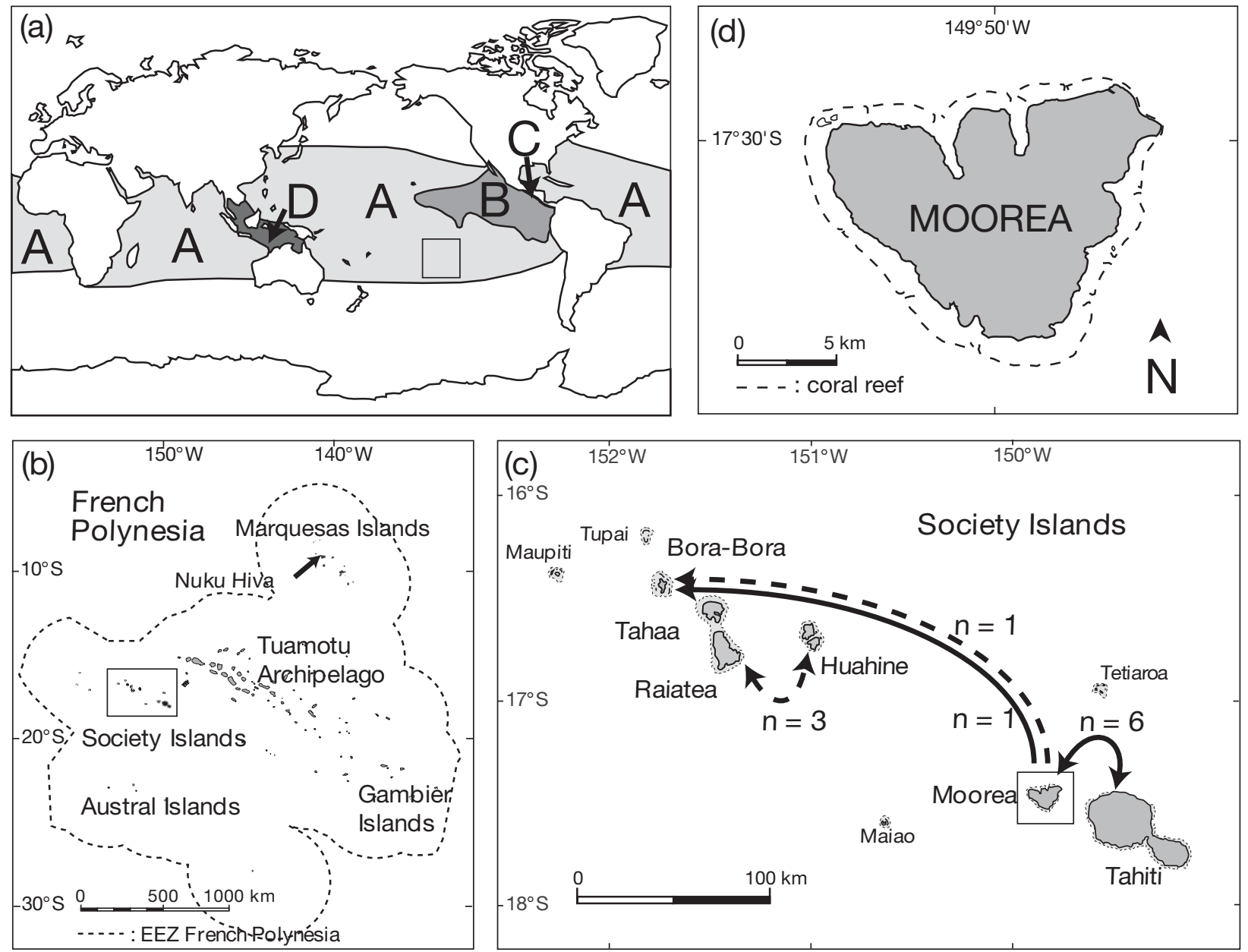

Fig. 1. Study area in relationship to the worldwide distribution of spinner dolphins. (a) Global distribution of spinner dolphins subspecies (from Galver 2002). A: Stenella longirostris longirostris, B: S. l. orientalis and whitebelly spinner dolphin, C: S. 1. centroamericana, D: S. l. roseiventris. Box: area of present study. (b) French Polynesia, including the Society Islands and Nuku Hiva in the Marquesas Islands. (c) Society Islands; arrows indicate movement of individuals between islands, based on photo-identification (bold solid line) and genotyping (bold dashed line). Number of events represented by each arrow is given. Dashed lines around Islands indicate coral reefs. (d) Moorea, the primary study site 
Gilpatrick 1994). Although absent from the ETP, its geographic distribution is much greater than the distribution of the other subspecies, extending across the tropical and subtropical waters of the Atlantic, Indian and Pacific Oceans (Fig. 1a). Much of what is known about the population dynamics of Stenella longirostris longirostris has been derived from a few island locations, including behavioural observation and photoidentification at the Big Island, Oahu, and Midway Atoll in Hawaii (Norris et al. 1994, Lammers 2004, Karczmarski et al. 2005), Fernando de Noronha in Brazil (Silva et al. 2005) and Moorea, in the Society Archipelago of French Polynesia (Poole 1995). These studies revealed that insular Gray's spinner dolphins (hereafter referred to as spinner dolphins) follow a similar daily cycle at each location; during the day, they rest and socialize in inshore habitats, and at dusk, they move offshore where they feed on squid, shrimp and mesopelagic fish. Demography and social structure, on the other hand, appear to be substantially different in each of the study locations.

Around the Big Island of Hawaii, where the dolphins use specific bays and shallow reefs during the daytime, Norris et al. (1994) found a 'fission-fusion' model of social organisation, with groups forming and separating from day to day. Because of the regular identification of new individuals in the resting groups, the authors concluded that the dolphins observed around this island form an open population of more than 1000 individuals (Norris et al. 1994). More recently, Karczmarski et al. (2005) described a very different social organisation of spinner dolphins at the remote atoll of Midway, in the far-western leeward Hawaiian Islands. This population of about 200 individuals was found to be closed (or nearly so) with respect to immigration/emigration, with strong geographic fidelity and no obvious fission-fusion (Karczmarski et al. 2005).

In the Society Archipelago of French Polynesia, Poole (1995) described an intermediate form of social organisation. Around the island of Moorea, the primary study site (Fig. 1), groups of spinners rest and socialise in a series of 10 pass/bay complexes (Fig. 1d). These groups follow the same fission-fusion model of social organisation observed at the Big Island, with day to day fluidity in group composition (Poole 1995). However, similar to Midway Atoll, photo-identification surveys over 6 yr indicated that Moorea's spinner dolphins were year-round, long-term residents, forming a small and apparently closed community, although some low-level of interchange was documented with the sister island of Tahiti, just $17 \mathrm{~km}$ away (Poole 1995).

These island-specific studies revealed important features of the behavioural ecology of insular spinner dolphins, but left unanswered several crucial questions related to genetic diversity and population dynamics: Do spinner dolphins typically form relatively closed island communities, distinct from one another, as suggested by observations at Moorea and Midway? What are the social and genetic boundaries of insular spinner dolphin communities? Is there any interchange of dolphins between island communities and at what frequency? Are island communities formed by colonization events followed by isolation or do they maintain connectivity to 'parent' populations, forming large metapopulations?

To address these questions, we combined evolutionary and demographic approaches, using microsatellite genotyping and mitochondrial DNA sequences obtained from biopsy samples and photographic sightingresighting of distinctively marked individuals, respectively, to describe community structure of spinner dolphins frequenting the near-shore island waters of the Society Archipelago, French Polynesia. First, to evaluate isolation or 'closure', we conducted intensive small-boat surveys at Moorea, investigating in detail the demography and genetic diversity of spinner dolphins around this island, and also taking advantage of the previous photo-identification study conducted by Poole (1995) from 1987 to 1992. Second, to address demographic and genetic connectedness, additional data (including biopsy samples and photographs) were collected around the main islands of the Society Archipelago and at Nuku Hiva in the Marquesas Archipelago, to provide insight on population structure at a larger scale (Fig. 1b). By combining demographic and evolutionary approaches on a local and regional scale, we hoped to provide a more comprehensive description of the long- and short-term dynamics of insular spinner dolphin populations.

\section{MATERIALS AND METHODS}

Study area and small-boat surveys. From April 2002 to November 2004, spinner dolphins were photographed and genetically sampled in French Polynesia, located in the central South Pacific Ocean (Fig. 1). We conducted small-boat surveys $(\mathrm{n}=189)$ around 6 islands of the Society Archipelago, including Moorea, Tahiti, Huahine, Raiatea, Tahaa and Bora Bora (Fig. 1c, Table 1). To avoid geographic bias in sampling, efforts were made to survey the entire coastline of each island with the exception of Tahiti. Surveys in Tahiti were conducted only in the eastern part of the island (from Point Venus to Papara) because of logistical limitations. Four boat surveys were also conducted at Nuku Hiva, in the Marquesas Archipelago, $1500 \mathrm{~km}$ north of Tahiti (Fig. 1b). The islands of Raiatea and Tahaa were considered 1 location (referred as Raiatea-Tahaa), 
Table 1. Stenella longirostris. Boat surveys conducted from 2002 to 2004 in French Polynesia. Q: quality rating; DMI: distinctively marked individual. -: no data available

\begin{tabular}{|c|c|c|c|c|c|c|c|}
\hline Island & Year & Start & End & $\begin{array}{c}\text { No. of } \\
\text { surveys }\end{array}$ & $\begin{array}{c}\text { No. of } \\
\text { encounters }\end{array}$ & $\begin{array}{c}\text { No. of photos } \\
\quad Q \geq 3\end{array}$ & $\begin{array}{l}\text { No. of } \\
\text { DMIs }\end{array}$ \\
\hline Moorea & $\begin{array}{l}2002 \\
2003\end{array}$ & $\begin{array}{l}18 \mathrm{Apr} \\
09 \mathrm{Jul}\end{array}$ & $\begin{array}{l}01 \mathrm{Nov} \\
10 \mathrm{Sep}\end{array}$ & $\begin{array}{c}107 \\
32\end{array}$ & $\begin{array}{c}126 \\
44\end{array}$ & $\begin{array}{c}6985 \\
792\end{array}$ & 25 \\
\hline Tahiti & $\begin{array}{l}2003 \\
2004\end{array}$ & $\begin{array}{l}28 \mathrm{Nov} \\
19 \text { Oct }\end{array}$ & $\begin{array}{l}01 \text { Dec } \\
31 \text { Oct }\end{array}$ & $\begin{array}{c}4 \\
12\end{array}$ & $\begin{array}{c}7 \\
19\end{array}$ & $\begin{array}{c}342 \\
1999\end{array}$ & 23 \\
\hline Bora Bora & 2003 & 19 Oct & 29 Oct & 6 & 3 & 144 & 2 \\
\hline $\begin{array}{l}\text { Raiatea- } \\
\text { Tahaa }\end{array}$ & $\begin{array}{l}2003 \\
2004\end{array}$ & $\begin{array}{l}29 \text { Oct } \\
04 \mathrm{Nov}\end{array}$ & $\begin{array}{l}04 \mathrm{Nov} \\
17 \mathrm{Nov}\end{array}$ & $\begin{array}{c}7 \\
14\end{array}$ & $\begin{array}{c}9 \\
20\end{array}$ & $\begin{array}{c}181 \\
1447\end{array}$ & 24 \\
\hline Huahine & 2003 & $05 \mathrm{Nov}$ & $12 \mathrm{Nov}$ & 7 & 6 & 288 & 5 \\
\hline Nuku Hiva & 2004 & $22 \mathrm{Nov}$ & $27 \mathrm{Nov}$ & 4 & 4 & - & - \\
\hline
\end{tabular}

since they are enclosed within the same lagoon. Moorea, Tahiti and Raiatea-Tahaa were visited on 2 consecutive years (Table 1).

Our primary study site was Moorea, where intensive boat surveys were conducted from April to November 2002 ( $\mathrm{n}=107$ ), and from July to September 2003 ( $\mathrm{n}=$ 32) (Table 1). We chose this island since a previous study was carried out there by Poole (1995), who conducted 275 boat surveys from 1987 to 1992, taking photographs of 249 groups of spinner dolphins. Poole (1995) also conducted 13 boat surveys along the northeast coast of Tahiti in 1988 and 1989.

Collection and analysis of photo-identification data. During each encounter, group size was estimated by visual counts, and dorsal fin photographs were taken of as many individuals as possible, regardless of distinctive marks. Photographs were taken using a digital Olympus E10 (4 megapixel charge-coupled device, CCD) equipped with a $200 \mathrm{~mm}$ lens and a Canon Digital Rebel (6.3 megapixel complementary metal-oxideSemiconductor, CMOS) equipped with a $300 \mathrm{~mm}$ lens. Dorsal fin photographs were first assessed for quality independently of distinctiveness of fins. Five criteria were used to assign photographs a quality rating (Q) on a scale of 1 to 5 (poor to excellent); focus, size, exposure, orientation and percentage of the dorsal fin visible on the photo (Arnborn 1987). Only images that rated $\mathrm{Q} \geq 3$ were considered for the analyses.

Most spinner dolphins showed some unique marks on their dorsal fins, but Poole (1995) found that, overall, only a limited percentage of individuals (about $15 \%$ of the population) are sufficiently distinctive to be confidently identified across time. Therefore, in our study, only dolphins with deep distinctive nicks or deformations on the edge of the dorsal fin were considered 'marked' for the purpose of individual identification. This allowed comparisons of images taken from either side of an individual. We refer to this subset of dolphins as 'distinctively marked individuals' (DMIs). All other photographed dolphins were classified as 'unmarked'.

Based on the images of DMIs collected during the surveys, a photoidentification catalogue was created for each island. All catalogues were compared to find resights within and between islands. Inter-annual resightings around the same island were also recorded for islands where surveys were conducted during 2 consecutive years. Finally, the DMI catalogues from this study were compared to Poole's (1995) catalogues comprising DMI photographs taken around Moorea and Tahiti between 1987 and 1992.

Biopsy sampling and DNA extraction. Skin samples for genetic analyses were collected from spinner dolphins using a small stainless-steel biopsy dart fired from a modified veterinary capture rifle equipped with a variable pressure valve (Krützen et al. 2002). All samples were preserved in $70 \%$ ethanol and stored at $-20^{\circ} \mathrm{C}$ for subsequent analysis. Total cellular DNA was isolated from skin tissue by digestion with Proteinase K followed by a standard phenol:chloroform extraction method (Sambrook et al. 1989) as modified for small samples by Baker et al. (1994).

Mitochondrial DNA (mDNA) sequencing, genotyping and sex identification. An 800 base pair (bp) fragment of the $5^{\prime}$ end of the mtDNA control region (dloop) was amplified using the polymerase chain reaction (PCR) and the primers light-strand, tProwhale M13-Dlp-1.5 (Dalebout et al. 1998), and heavy strand, Dlp-8G (designed by G. Lento as reported in Dalebout et al. 2005). All amplification reactions were carried out in a total volume of $20 \mu$ with $1 \times$ AmpliTaq buffer, $2.5 \mathrm{mM} \mathrm{MgCl}_{2}, 0.4 \mu \mathrm{M}$ of each primer, $0.2 \mathrm{mM}$ deoxynucleoside triphosphate (dNTP) and $0.5 \mathrm{U}$ of Ampli-Taq ${ }^{\circledR}$ DNA polymerase. The PCR temperature profile was as follows: a preliminary denaturing period of $2 \mathrm{~min}$ at $94^{\circ} \mathrm{C}$ followed by 35 cycles of denaturation for $30 \mathrm{~s}$ at $94^{\circ} \mathrm{C}$, primer annealing for $45 \mathrm{~s}$ at $55^{\circ} \mathrm{C}$ and polymerase extension for $40 \mathrm{~s}$ at $72^{\circ} \mathrm{C}$. A final extension period of $10 \mathrm{~min}$ at $72^{\circ} \mathrm{C}$ was included at the end of the cycle. PCR products were purified for sequencing with ExoSAP-IT (USB) and sequenced in both directions with BigDye ${ }^{\mathrm{TM}}$ terminator chemistry v.3.1 on an ABI3100 DNA sequencer (Applied Biosystems). Sequences were aligned using Sequencher ${ }^{\mathrm{TM}}$ 
(version 4.1.2, Gene Codes) and edited manually. Variable sites and unique haplotypes were identified using MacClade version 4.0 (Maddison \& Maddison 2000).

Samples were genotyped using 12 published microsatellite loci developed from other cetacean species (Table 2). Amplification via PCR was performed following standard protocols, in $10 \mu \mathrm{l}$ volumes, with $1.5 \mathrm{mM} \mathrm{MgCl}_{2}$ and annealing temperature varying by locus (Table 2). PCR products were run on an ABI 377 DNA automated sequencer with a TAMRA350 size ladder (Applied Biosystems). Data were collected by GeneScan version 3.7, and the fragment size was measured using GENOTYPER version 2.5 (Applied Biosystems). The sex of sampled dolphins was identified by amplification of a fragment of the sry gene multiplexed with Fragments of the ZFY/ZFX genes as positive control, and as described by Gilson et al. (1998).

Moorea community size estimate. An extensive photographic collection at Moorea allowed estimation of the dolphin community size. We chose the Bowden estimator for closed populations (Bowden \& Kufeld 1995), as implemented in the program NOREMARK (White 1996a). This model requires only a small proportion of the population to be marked and provides an estimate of the total population size and confidence intervals, taking into account the frequency of sightings of each marked individual and the total number of sightings for unmarked individuals. It allows for continuous sampling over long periods of time, removing the need to subdivide the dataset into sampling periods. This estimator is robust to heterogeneity of sighting probabilities (White 1996b).

Table 2. Stenella longirostris. Microsatellite diversity in French Polynesia. $H_{0}$ :observed heterozygosity; $H_{\mathrm{e}}$ : expected heterozygosity. No significant deviation $(\mathrm{p}>0.05)$ was found after Bonferroni correction $\left(\mathrm{p}_{\text {crit }}=0.042\right) . k$ : number of found alleles; $\mathrm{n}$ : number of screened chromosomes. Superscripts indicate different PCR temperature profiles: ${ }^{a} 94^{\circ} \mathrm{C}$ for $10 \mathrm{~min}$, followed by 35 cycles of $94^{\circ} \mathrm{C}$ for $30 \mathrm{~s}, 50^{\circ} \mathrm{C}$ for $30 \mathrm{~s}$ and $72^{\circ} \mathrm{C}$ for $30 \mathrm{~s}$, with a final extension at $72^{\circ} \mathrm{C}$ for $3 \mathrm{~min}$; ${ }^{\mathrm{b}} 94^{\circ} \mathrm{C}$ for $10 \mathrm{~min}$, followed by 30 cycles of $94^{\circ} \mathrm{C}$ for $30 \mathrm{~s}, 55^{\circ} \mathrm{C}$ for $30 \mathrm{~s}$ and $72^{\circ} \mathrm{C}$ for $20 \mathrm{~s}$, with a final extension at $72^{\circ} \mathrm{C}$ for $3 \mathrm{~min}^{\mathrm{c}}{ }^{\mathrm{c}}$ as reported in the original paper

\begin{tabular}{|c|c|c|c|c|c|c|}
\hline Loci & $k$ & $\mathrm{n}$ & $H_{\mathrm{o}}$ & $H_{\mathrm{e}}$ & $\begin{array}{l}\text { Null allele } \\
\text { frequencies }\end{array}$ & Source \\
\hline GATA98 & 9 & 137 & 0.825 & 0.815 & -0.0069 & Palsbøll et al. (1997) ${ }^{\mathrm{a}}$ \\
\hline MK5 & 12 & 137 & 0.825 & 0.823 & +0.0013 & Krützen et al. $(2001)^{a}$ \\
\hline PPHO142 & 10 & 132 & 0.674 & 0.677 & +0.0010 & Rosel et al. $(1999)^{b}$ \\
\hline EV94 & 20 & 136 & 0.816 & 0.849 & +0.0164 & Valsecchi \& Amos (1996) \\
\hline GT575 & 8 & 135 & 0.726 & 0.775 & +0.0305 & Bérubé et al. $(2000)^{\mathrm{b}}$ \\
\hline KWM12a & 11 & 136 & 0.838 & 0.821 & -0.0121 & Hoelzel et al. $(1998)^{a}$ \\
\hline PPHO131 & 14 & 137 & 0.861 & 0.855 & -0.0036 & Rosel et al. $(1999)^{\mathrm{b}}$ \\
\hline MK6 & 19 & 136 & 0.809 & 0.875 & +0.0395 & Krützen et al. $(2001)^{a}$ \\
\hline GT6 & 10 & 135 & 0.726 & 0.771 & +0.0298 & Caldwell et al. $(2002)^{a}$ \\
\hline AAT44 & 10 & 136 & 0.757 & 0.812 & +0.0346 & Caldwell et al. $(2002)^{\mathrm{c}}$ \\
\hline $415 / 416$ & 12 & 132 & 0.788 & 0.833 & +0.0274 & Amos et al. $(1993)^{b}$ \\
\hline EV1 & 15 & 136 & 0.743 & 0.843 & +0.0623 & Valsecchi \& Amos (1996) \\
\hline
\end{tabular}

Abundance was also estimated with the program CAPWIRE (Miller et al. 2005), using the frequency of capture-recapture found by genotyping biopsy samples. This method, based on a simple urn model, assumes a closed population and can be applied using a single continuous sampling session. Simulations showed that it performs better than commonly used capture-recapture models when population size is small (not more than a few hundred individuals) and when heterogeneity occurs in capture probability (Miller et al. 2005). We tested for equal likelihood of capture by comparing the frequencies of capture to the zero-truncated Poisson distribution as described by Caughley (1977). Biopsy samples were collected without consideration of previous sampling of marked or unmarked individuals and therefore provided a dataset independent of photo-identification for the purpose of capture-recapture analyses.

mtDNA and microsatellite diversity. The software ARLEQUIN v3.01 (Excoffier et al. 2005) was used to estimate the number of polymorphic sites, as well as haplotype diversity $(h)$ and nucleotide diversity $(\pi)$ of mtDNA control region, overall and for each island. to computer limitations, we could not use the model of substitution proposed by MODELTEST (Posada \& Crandall 1998), i.e. HKY+I+G; transi(ti/tv) ratio $=37.79 ;$ gamma correc0.4941, but instead used the closely related rection of 0.4941

Microsatellite loci were tested for departure from Hardy-Weinberg equilibrium using ARLEQUIN, and the potential frequency of null alleles was estimated using CERVUS v2.0 (Marshall et al. 1998). The probability of identity was estimated, as implemented in the program GenAlEx (Peakall \& Smouse 2006), and the matching genotypes, assumed to represent replicate samples of individuals, were found with CERVUS. The number of alleles per locus and allelic richness were calculated with the program FSTAT v.2.9.3.2 (Goudet 2001).

Population structure and sex-specific dispersal. A median-joining network was reconstructed to infer phylogenetic relationship among the mtDNA control region haplotypes, using the program NETWORK v.4.1.0.8 (Bandelt et al. 1999). Analyses of molecular variance (AMOVA) were conducted with ARLEQUIN, grouping animals by islands based on the mtDNA control region (using $F_{\mathrm{ST}}$ and $\Phi_{\mathrm{ST}}$ ) and on the 
microsatellite loci (using $F_{\mathrm{ST}}$ ). The $\Phi_{\mathrm{ST}}$ statistic takes into account the relationship between haplotypes based on molecular distances, while the $F_{\mathrm{ST}}$ uses only the difference in frequencies of haplotype (Excoffier et al. 1992).

To test for bias in dispersal between males and females, we analysed microsatellite genotypes and mtDNA (by coding individuals as homozygotes) using the 'biased dispersal' option implemented in FSTAT (Goudet 2001). From this program, we report 2 tests that seem to perform best across a range of conditions (Goudet et al. 2002): the comparison of sex-specific $F_{\mathrm{ST}}$ values and the sex-specific variance of assignment index (vAIc) (Goudet et al. 2002). For the $F_{\mathrm{ST}}$ test, the value of the more dispersing sex is expected to be lower than that of the more philopatric sex. For the vAIc test, variance is expected to be higher in the dispersing sex. The significance of both tests was judged by generating null distributions with 10000 permutations.

Female long-term effective population size $\left(N_{\mathrm{ef}}\right)$. For comparison to the estimated census size of local communities, we estimated $N_{\text {ef }}$ for island samples based on mtDNA diversity. We used the relationship, $N_{\text {ef }}=\theta_{\mathrm{f}} / 2 \mu$, where $\mu$ is the neutral mutation rate per nucleotide per generation and $\theta_{\mathrm{f}}$ is, in this case, a measure of mtDNA diversity. The parameter $\theta_{\mathrm{f}}$ was estimated with the maximum likelihood coalescent approach implemented in the program LAMARC v.2.0 (Kuhner 2006); searches included 10 short chains (500 trees used of 10000 sampled) and 2 long chains (10 000 trees used of 200000 sampled). We performed 3 runs of LAMARC for each sample, and we choose the median value for a final $N_{\text {ef }}$ estimate. For $\mu$, we calculated a mutation rate of 7.46 to $9.35 \times 10^{-9}$ nucleotides $\mathrm{yr}^{-1}(\lambda=$ $\mathrm{d} / 2 T$ ) from the evolutionary distance $(d)$ of $0.1775 \pm$ 0.0283 between Delphinidae and Phocoenidae (using our dataset and a harbour porpoise sequence from GenBank, accession number AJ554063; Arnason et al. 2004), and an assumed divergence time ( $T$ ) of 1.0 to 1.1 $\times 10^{7}$ years ago based on the fossil record (Barnes 1985). Such a mutation rate is comparable to mutation rates previously reported for baleen whales (Baker et al. 1993) and Cuvier's beaked whales (Dalebout et al. 2005). The value was adjusted using a generation time of $15 \mathrm{yr}$ for spinner dolphins, estimated as the average age of mature females following data from Perrin \& Henderson (1984), for a final mutation rate estimate of $\mu=1.12$ to $1.40 \times 10^{-7}$ nucleotides per generation.

Testing for a recent bottleneck effect. The sample of mtDNA sequences from each island was tested for departure from mutation-drift equilibrium with Tajima's $D$ test (Tajima 1989b) and Fu's Fs test (Fu 1997), as implemented in ARLEQUIN. A positive Tajima's $D$ can indicate an admixture of 2 distinct pop- ulations, while a negative Tajima's $D$ can be explained by a recent bottleneck effect or population expansion (Tajima 1989a, Aris-Brosou \& Excoffier 1996). Large negative values of Fu's $F$ s statistics can also indicate a population demographic expansion (Fu 1997). Significance of both statistics was inferred by randomisation (10 000 steps), using a coalescent simulation algorithm (Hudson 1990) as implemented in ARLEQUIN.

For microsatellites, we used a test implemented in the program BOTTLENECK v.1.2.02 (Cornuet \& Luikart 1996), based on allele frequencies; the Wilcoxon 1-tailed test for heterozygote excess, run under the stepwise mutation model (SMM) and the 2-phased model $(\mathrm{TPM}$; variance $=30,70 \%$ stepwise mutational model, 1000 iterations). The distribution of allelic frequencies was also inspected to detect a mode-shift distortion due to the loss of rare alleles (Luikart et al. 1998). Finally, we applied the method implemented in the programs M_P_Val and Critical_M (Garza \& Williamson 2001), to test if the $M$ ratios (mean ratio of the number of alleles to the range in allele size) of island samples were significantly smaller than expected under a range of expected neutral values. Expected values of $M$ were simulated assuming a TPM, with parameters $\Delta_{\mathrm{g}}=3.5$ and $p_{\mathrm{s}}=90 \%$ where $\Delta_{\mathrm{g}}$ is the average size of non 1-step mutations and $p_{\mathrm{s}}$ is the proportion of 1-step mutations (Garza \& Williamson 2001) and considering $\theta$ values of 1,10 and 50 , i.e. pre-bottleneck population sizes ranging from 500 to 25000 when $\mu=5$ $\times 10^{-4}$ nucleotides per generation (Goldstein \& Schlötterer 1999).

\section{RESULTS}

\section{Survey efforts and sample sizes}

Groups of spinner dolphins were found around all 6 islands surveyed. The number of encounters at each island ranged from 6 to 170 (Table 1), and was highly correlated with the number of surveys (Spearman's $\mathrm{r}_{\mathrm{S}}=$ $0.94 ; \mathrm{p}<0.005$ ). Average group size was 36.4 dolphins (ranging from 3 to 90). A large number of photographs was taken for individual identification (Table 1), particularly at Moorea in 2002. From the photographs, a total of 82 DMIs were identified, with the largest numbers identified around Moorea, Tahiti and Raiatea-Tahaa (Table 1). No DMIs were identified at Nuku Hiva.

A total of 154 genetic samples were collected from dolphins around all islands visited during this study (Table 3); 152 were biopsy samples and 2 were samples from dead stranded dolphins (Moorea, January 2003, n $=2$ ). Biopsy samples were collected from 79 different groups of dolphins (Table 3). Each sample 
Table 3. Stenella longirostris. Sex identification and genetic diversity statistics for microsatellite loci and the mitochondrial DNA (mDNA) control region. The column for the Society Archipelago encompasses data collected at Moorea, Tahiti, Bora Bora, Raiatea-Tahaa and Huahine, and are indicated in bold. $k$ : mean number of alleles per locus (across 12 loci). For the mtDN control region: $h$, haplotype diversity; $\pi$, nucleotide diversity. $N_{\mathrm{ef}}$ (in thousands): estimated female long-term effective population size

\begin{tabular}{|c|c|c|c|c|c|c|c|}
\hline & Moorea & Tahiti & Bora Bora & Raiatea-Tahaa & Huahine & Society Archipelago & Nuku Hiva \\
\hline No. of samples & 70 & 34 & 6 & 19 & 17 & 146 & 8 \\
\hline No. of individuals & 59 & 33 & 6 & 16 & 15 & 129 & 8 \\
\hline No. of groups & 41 & 17 & 3 & 10 & 4 & 75 & 4 \\
\hline No. of females & 20 & 13 & 3 & 8 & 3 & 47 & 3 \\
\hline No. of males & 39 & 19 & 3 & 8 & 12 & 81 & 5 \\
\hline \multicolumn{8}{|l|}{ Microsatellites } \\
\hline$k$ & 10.42 & 7.50 & 5.42 & 8.33 & 8.67 & 11.92 & 7.50 \\
\hline Allelic richness & 5.59 & 4.85 & 5.42 & 5.79 & 6.13 & 5.64 & 5.84 \\
\hline \multicolumn{8}{|l|}{ mtDNA } \\
\hline No. of haplotypes & 18 & 4 & 5 & 12 & 10 & 27 & 5 \\
\hline$h$ & $0.93 \pm 0.01$ & $0.47 \pm 0.08$ & $0.93 \pm 0.12$ & $0.97 \pm 0.03$ & $0.95 \pm 0.03$ & $0.90 \pm 0.02$ & $0.86 \pm 0.11$ \\
\hline$\pi(\%)$ & $1.62 \pm 0.84$ & $0.64 \pm 0.37$ & $1.69 \pm 1.04$ & $1.73 \pm 0.94$ & $1.54 \pm 0.85$ & $1.48 \pm 0.77$ & $1.43 \pm 0.85$ \\
\hline$N_{\text {ef }}$ & 103 & 23 & 103 & 169 & 112 & 127 & 74 \\
\hline$(95 \% \mathrm{CI})$ & $(76-190)$ & $(12-52)$ & $(42-390)$ & $(96-398)$ & $(60-275)$ & $(100-200)$ & $(32-239)$ \\
\hline
\end{tabular}

was genotyped at 9 to 12 microsatellite loci. All loci were found to be highly polymorphic, overall (Table 2) and within island samples (Table 3 ). The probability of identity was $6.8 \times 10^{-12}$, when calculated across the first 9 loci (the minimum number of loci successfully genotyped for each sample), and $8.59 \times 10^{-16}$ over 12 loci. Comparison of genotypes from the 154 biopsies revealed that 17 individuals were sampled on 2 occasions while 2 were sampled on 3 occasions (i.e. 19 individuals sampled more than once). All other pairwise comparisons showed mismatches at 5 or more loci between individuals, making false exclusion (due to genotyping error) highly unlikely. From these data, we concluded that a total of 133 individual dolphins were sampled during this study.

\section{Demographic closure at Moorea}

Photo-identification records from intensive boat surveys at Moorea in 2002 to 2003 were used to assess the degree of demographic closure/openness of this insular community. A total of 126 groups of spinner dolphins were encountered around Moorea in 2002 and 44 in 2003. Over both years, 6892 photographs of $\mathrm{Q} \geq 3$ were taken, from which 24 DMIs were identified. The discovery curve, based on the cumulative number of new DMIs across a 2 yr scale of study, supported Poole's (1995) previous findings that spinner dolphins around Moorea are part of a demographically closed community (Fig. 2). In 2002, the discovery curve of the DMIs increased during the first 25 surveys but then reached an asymptote for 2.5 mo at 18 DMIs (44 encounters) (Fig. 2). Based on their pattern of frequent resightings, these DMIs were considered 'regular members' of the community frequenting Moorea's near-shore waters in 2002. Of these 18 individuals, 17 were photographically resighted on 13 to $37 \mathrm{~d}$ throughout the field season. The remaining individual was not seen after June 6, although it was resighted on $6 \mathrm{~d}$ during the first 2 mo of surveys.

On 28 and 29 August 2002, 5 new DMIs were photographed together (Fig. 2). After these 2 consecutive encounters, these 5 new DMIs were never seen again at Moorea. Considering these 2 sightings and also subsequent resightings of 4 of these 5 dolphins at Tahiti (see below), these animals were considered to be 'visitors' (i.e. temporary immigrants) to Moorea. Another new DMI was identified at Moorea in late 2002 (Fig. 2), but its fresh scars suggested a newly acquired mark rather than immigration.

During the surveys conducted from July to September 2003, 17 DMIs were photographically identified on 2 to 10 occasions each (Fig. 2). Only 1 of these was not known from the previous 2002 surveys, but it could not be determined if it was a visitor, a recent immigrant, or a previous member of the community with recently acquired but already healed scars. Apart from this last DMI, photo-identification data collected in 2003 did not alter the asymptote of the discovery curve started in 2002 (Fig. 2), suggesting strong community stability over the $2 \mathrm{yr}$ of surveys. An independent discovery curve using only the 2003 photographs reached an asymptote after only 20 surveys (Fig. 2).

Comparison to the data of Poole (1995) showed that 5 of the DMIs identified as members of the community in 2002 to 2003 had been regularly photographed previously around Moorea between 1987 and 1992. These 5 DMIs, 3 of which were first identified in 1987 as adults (i.e. at least 5 yr old), were also regularly photographed 


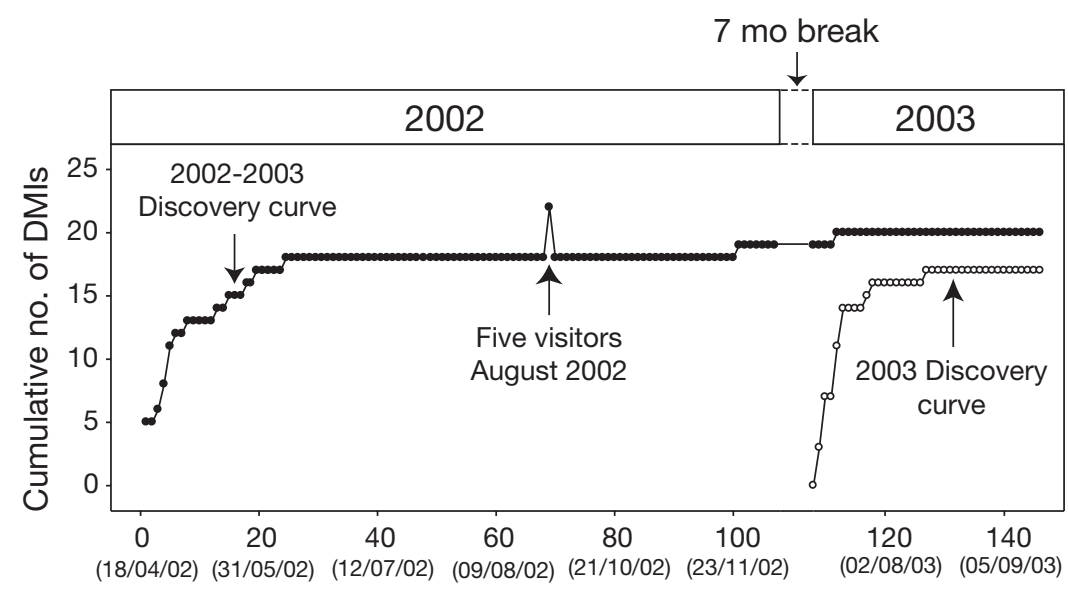

No. of surveys (Dates in $\mathrm{d} / \mathrm{mo} / \mathrm{yr}$ )

Fig. 2. Stenella longirostris. Discovery curves based on the cumulative number of new distinctively marked individuals (DMIs) identified at Moorea in 20022003 (•) and in 2003 only (O). Identification of 5 visitors in August 2002 is indicated by a spike

around Moorea between the 1987-1992 study and the 2002-2003 study (Poole unpubl. data), supporting site fidelity of up to 15 yr. Based on field observations and/or molecular data, we found that these 5 dolphins included at least 2 females and 1 male (females: Slo02Mo15 and Slo02Mo16; male: Slo02Mo27).

\section{Abundance of the Moorea community}

The abundance of the Moorea community was estimated based on the frequency of photographic recapture of the 18 DMIs identified as 'regular members' of the community during 2002. During the 106 encounters considered for the purpose of the estimate, the 18 DMIs were photographed from 13 to 84 times each (based on $\mathrm{Q} \geq 3$ photos), giving a total of 811 sighting-resighting events. Photographs of unmarked individuals $(\mathrm{Q} \geq 3)$ represented 5295 'sightings'. Based on the frequencies of resighting of each DMI and on the total number of unmarked individual sightings, the Bowden estimator gave an abundance of 135 (95\% CI, 112 to 163) for the Moorea community. As expected, our estimate was slightly larger (due to demographic effects) when including the 2003 photographs (148, 95\% CI 121 to 181).

To corroborate the estimate from photo-identification, the abundance of the Moorea community was also estimated by genotyping. Unlike the photo-identification, all individuals were expected to be uniquely identifiable by genotyping, but the number of sampling events was much smaller. Of the total 62 skin samples collected around Moorea in 2002, comparison of genotypes revealed that 42 individuals were sampled once, 7 were sampled twice and 2 were sampled on 3 occasions. Comparison to a zero-truncated Pois- son distribution indicates that dolphins had unequal likelihood of biopsy sampling $\left(\chi^{2}=6.67, \mathrm{p}<0.01\right)$. Based on these frequencies of capture-recapture, the program CAPWIRE provided an estimate of 151 individuals $(95 \% \mathrm{CI}$, 97 to 294), showing relatively close agreement with the Bowden estimate based on photo-identification.

\section{Individual interchange among islands}

Comparison among DMIs from all islands provided insight into low levels of demographic interchanges and temporary immigration. Of the 23 DMIs identified at Tahiti, 6 were encountered during surveys conducted at Moorea in 2002 and 2003. Two of these dolphins were known members of the Moorea community. The other 4 DMIs were the 'visitors' observed at Moorea in August 2002, further supporting the particular status of these dolphins. A review of photographs collected previously by Poole (1995) showed that one of these 'visitors' was first identified at Tahiti in 1989. No matching of DMIs was found between Huahine (5 DMIs), Raiatea-Tahaa (24 DMIs) and Bora Bora (2 DMIs), although these islands are geographically close to one another (Fig. 1C). Surprisingly, 1 DMI was observed at both Moorea and Bora Bora, more than $200 \mathrm{~km}$ distant from each other (Fig. 1). This dolphin was the DMI regularly observed at Moorea for the first 2 mo of surveys conducted in 2002 but not seen after June (see above), suggesting a long-term (perhaps permanent) emigration from Moorea.

Comparison of genotypes from biopsy samples collected at the outer islands provided additional information on individual interchange among islands. Most of the recapture events were around the island where the individuals were initially sampled (11 at Moorea, 1 at Tahiti, 2 at Huahine and 3 at Raiatea-Tahaa), but 4 dolphins were resampled at different islands. Among them, 3 dolphins (all males) were biopsied in both Huahine and Raiatea, demonstrating at least occasional interchange between these 2 islands. No genotype match was found between Moorea and Tahiti. Finally, a female sampled at Moorea in May 2002 was resampled at Bora Bora in 2003. This genetic recapture supports the other immigration event between these 2 islands illustrated by the recapture of the DMI.

Replicate samples of individuals collected around the same islands $(n=17)$ were removed from the dataset for subsequent analyses of genetic diversity, population structure, sex-dispersal and bottleneck tests. 
However, replicate samples from different islands $(\mathrm{n}=$ 4) were retained for these analyses, except where mentioned, providing a total sample size of 137 individuals.

\section{mtDNA diversity and effective population size}

Considering the relative demographic closure of insular communities, levels of mitochondrial genetic diversity were surprisingly high at Moorea and for the other island samples. Across the $555 \mathrm{bp}$ consensus region of the mtDNA control region, we found 52 variable sites defining 31 haplotypes (GenBank accession numbers
EF558737 to EF558767) for the 59 individuals. The overall haplotype diversity was $0.92 \pm 0.014$ and nucleotide diversity was $1.59 \% \pm 0.82 \%$ (Table 3 ). Similar levels of diversity were observed for other within-island samples, except in Tahiti, which showed much lower levels of haplotype and nucleotide diversity (Table 3). There were no obvious differences in mtDNA control region diversity between males $(n=83)$ and females $(n=49)$ (results not shown).

The median-joining network of mtDNA haplotypes showed no obvious overall phylogeographic structuring but did indicate a striking absence of expected sister lineages, i.e. haplotypes related by a single substitution to observed haplotypes (Fig. 3). Samples from

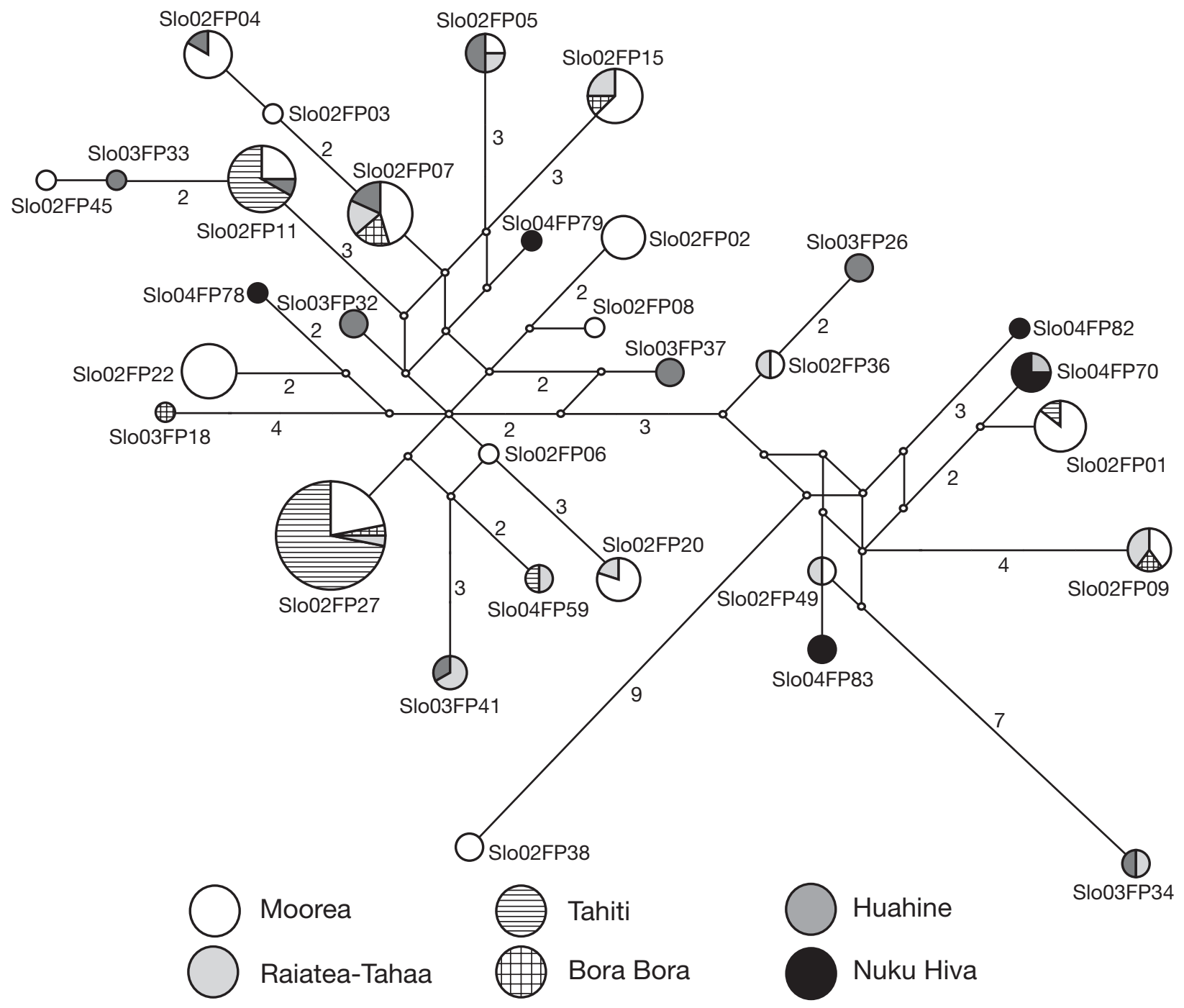

Fig. 3. Stenella longirostris. Inferred genealogical relationship among mtDNA haplotypes $(n=31)$ in spinner dolphins from French Polynesia based on the median-joining algorithm. The diameter of each circle is proportional to the number of individuals found for the haplotype $\left(\mathrm{n}_{\text {ind }}=137\right)$. White dots represent inferred node haplotypes not found in the samples. Length of the branches is proportional to the number of inferred mutational steps that they represent (number of inferred mutational steps is indicated when $>1$ ). Codes refer to individuals chosen to represent haplotypes 
Tahiti were dominated by a few haplotypes (Slo02FP11 and Slo02FP27) shared with several other islands of the Society Archipelago. Huahine showed 4 unique haplotypes, while Bora Bora had 1 and Raiatea-Tahaa had none. Moorea had the largest number of unique haplotypes $(\mathrm{n}=7)$, but it also represented the largest data set. Finally, 4 of the 5 haplotypes identified at Nuku Hiva, in the remote Marquesas Islands, were not found in the Society Archipelago.

Based on our estimated substitution rate of 1.12 to $1.40 \times 10^{-7}$ nucleotides per generation, estimates of long-term $N_{\text {ef }}$ for each island sample ranged from 23000 to 169000 (Table 3). We note that the estimate of $N_{\text {ef }}$ at Moorea $\left(N_{\text {ef }}=103000\right)$ showed obvious discrepancy with the current census size estimates $\left(N_{\text {census }}<\right.$ 200). Interestingly, long-term $N_{\text {ef }}$ estimated for the entire Society Archipelago was of the same order as estimates from single islands (such as Moorea, Raiatea and Huahine).

Table 4. Stenella longirostris. Genetic differentiation among island communities based on pairwise $F$-statistics. Below the diagonal, genetic distances are given for mtDNA control region sequence data: first line, $F_{\mathrm{ST}}$ values; second line, $F_{\mathrm{ST}}$ values. Above diagonal, $F_{\mathrm{ST}}$ values are given for the 12 microsatellite loci. ${ }^{* * *} \mathrm{p}<0.001 ;{ }^{* *} \mathrm{p}<0.01 ;{ }^{*} \mathrm{p}<0.05 ;$ ns: $\mathrm{p}>0.05$. Values of $\mathrm{p}<0.05$ are in bold

\begin{tabular}{|c|c|c|c|c|c|c|}
\hline & Moorea & Tahiti & $\begin{array}{l}\text { Bora } \\
\text { Bora }\end{array}$ & $\begin{array}{c}\text { Raiatea- } \\
\text { Tahaa }\end{array}$ & Huahine & Nuku Hiva \\
\hline Moorea & & $0.015^{* * *}$ & $0.038^{* *}$ & $0.019^{* * *}$ & $0.017^{* *}$ & $0.048^{* * *}$ \\
\hline Tahiti & $\begin{array}{l}0.205^{* * *} \\
0.170^{* * *}\end{array}$ & & $0.075^{* * *}$ & $0.043^{* * *}$ & $0.042^{* * *}$ & $0.084^{* * *}$ \\
\hline Bora Bora & $\begin{array}{l}-0.001^{\mathrm{ns}} \\
-0.042^{\mathrm{ns}}\end{array}$ & $\begin{array}{l}0.289^{* *} \\
0.267^{* *}\end{array}$ & & $0.026^{*}$ & $0.028^{*}$ & $0.078^{* * *}$ \\
\hline $\begin{array}{c}\text { Raiatea- } \\
\text { Tahaa }\end{array}$ & $\begin{array}{l}0.011^{\mathrm{ns}} \\
0.017^{\mathrm{ns}}\end{array}$ & $\begin{array}{l}0.281^{* * *} \\
0.297^{* * *}\end{array}$ & $\begin{array}{l}-0.050^{\mathrm{ns}} \\
-0.038^{\mathrm{ns}}\end{array}$ & & $0.009^{\mathrm{ns}}$ & $0.029^{* *}$ \\
\hline Huahine & $\begin{array}{l}\mathbf{0 . 0 3 6}^{*} \\
0.021^{\text {ns }}\end{array}$ & $\begin{array}{l}0.315^{* * *} \\
0.258^{* * *}\end{array}$ & $\begin{array}{r}0.012^{\mathrm{ns}} \\
-0.037^{\mathrm{ns}}\end{array}$ & $\begin{array}{l}0.003^{\text {ns }} \\
0.026^{\text {ns }}\end{array}$ & & $0.030^{* *}$ \\
\hline Nuku Hiva & $\begin{array}{l}0.098^{* *} \\
0.138^{* *}\end{array}$ & $\begin{array}{l}0.399^{* * *} \\
0.519^{* * *}\end{array}$ & $\begin{array}{l}0.107^{\text {ns }} \\
\mathbf{0 . 1 8 4}^{*}\end{array}$ & $\begin{array}{l}\mathbf{0 . 0 6 2}^{*} \\
0.049^{\text {ns }}\end{array}$ & $\begin{array}{l}0.091^{* * *} \\
0.196^{* *}\end{array}$ & \\
\hline
\end{tabular}

\section{Population differentiation}

An AMOVA showed significant differentiation in mtDNA variation among the 6 island communities at both the haplotype and nucleotide level $\left(F_{\mathrm{ST}}=0.143\right.$; $\left.\Phi_{\mathrm{ST}}=0.129 ; \mathrm{p}<0.001\right)$. Pairwise comparisons showed that the overall effect was strongly influenced by Tahiti and Nuku Hiva despite the small sample size of the latter (Table 4). Nonetheless, significant differences were also found between Moorea and Huahine based on $F_{\mathrm{ST}}$ (although not for $\Phi_{\mathrm{ST}}$ ).

Analysis of the microsatellite loci also showed significant differentiation among islands, but it was weaker than that obtained from mtDNA $\left(F_{\mathrm{ST}}=0.029 ; \mathrm{p}<0.001\right)$. Pairwise comparisons showed significant differentiation between all communities except Raiatea and Huahine. Even here, when the 3 individuals found in both datasets were excluded from the analysis (since they were sampled at both locations), differences between these 2 islands were significant $(\mathrm{p}=0.014)$. There was no evidence of null alleles or significant deviation from Hardy-Weinberg expectations for the overall sample.

\section{Sex-biased dispersal}

Sex-specific AMOVAs showed significant population differentiation for males and females at both the nuclear and mitochondrial level, discounting the null hypothesis of panmixia for either sex (Table 5). However, these analyses showed a trend toward larger $F_{\mathrm{ST}}$ values for females at both the mtDNA control region and microsatellite loci, suggesting greater female philopatry and some male-biased dispersal, although the effect was not significant given our sample sizes. This trend was confirmed by the

Table 5. Stenella longirostris. Differences in sex-specific $F_{\mathrm{ST}}$ values and variance of corrected assignment index (nAic), based on the mtDNA control region and microsatellite loci. Results are reported for tests including (repli) or not including (no repli) the replicate samples obtained from different islands (p-values in bold). -: no values calculated. Significance levels of genetic differentiation, estimated with ARLEQUIN v.3.01, are also indicated for $F_{\mathrm{ST}}$ values. ${ }^{* * *} \mathrm{p}<0.001$; ${ }^{*} \mathrm{p}<0.05$; ns: $\mathrm{p}>0.05$

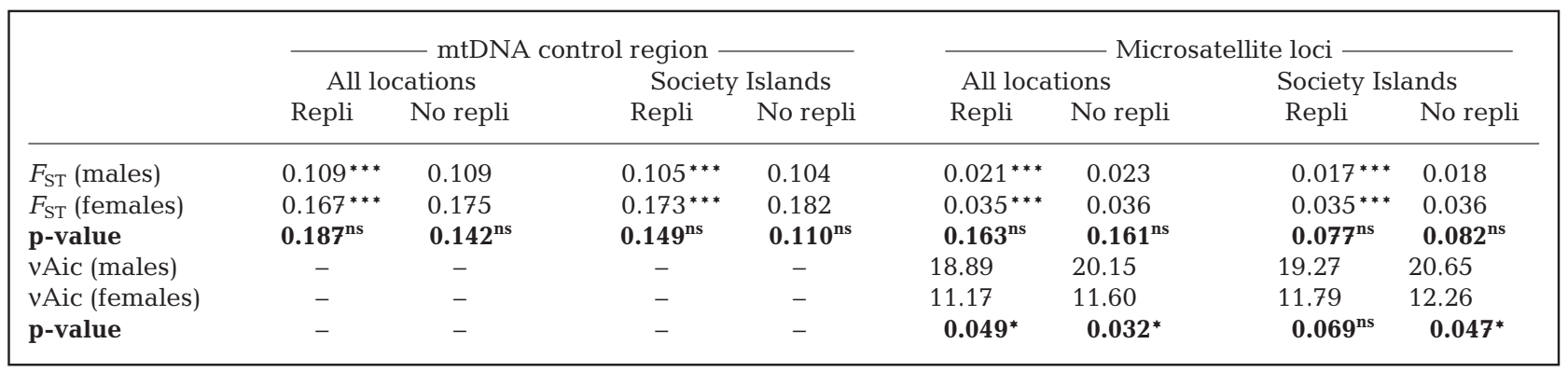


test of variance of the vAic test, which was significant regardless of whether the 4 replicate samples were included (Table 5).

To evaluate sex-biased dispersal on a smaller geographical scale, we carried out the same tests considering only samples from the Society Islands (Table 5). The same trend of larger $F_{\mathrm{ST}}$ for females and larger $\mathrm{VAIC}$ for males were observed within this dataset (i.e. supporting dispersal biased toward males). In this case, vAIC tests were only significant when the 4 replicate samples from different islands were excluded (Table 5).

\section{Genetic signature of a community bottleneck}

Various tests based on the mtDNA control region and microsatellite loci failed to detect the signature of a recent bottleneck effect in the island communities. Tajima's and Fu's tests for mtDNA did not differ significantly from expected under a neutral model of evolution for any of the data sets, except Tahiti, which showed a significantly positive Fu's Fs value (Table 6). Similarly, the 3 tests for a bottleneck using allele frequencies of microsatellite loci showed no evidence of a recent population decline or colonization event. No significant heterozygosity excess was found after correcting for multiple comparisons (Rice 1989) (Table 6), and the distribution of allelic frequencies did not show significant departure from a standard L-shape in the mode-shift test, indicating no loss of rare alleles in any of the communities (results not shown). Finally, applying the approach of Garza \& Williamson (2001), observed Mvalues (Table 6) were consistent with the null distribution $(\mathrm{p}>$ 0.05 ) under the expectation of equilibrium for all the islands and at the different $\theta$ values considered.

\section{DISCUSSION}

\section{Demographic closure of the Moorea community}

The photo-identification surveys conducted at Moorea in 2002 and 2003 support Poole's (1995) previous observation that on an intra-generational time scale, spinner dolphins using the near-shore waters of this island form a small and relatively closed community. The resightings in 2002 of 5 DMIs previously known as members of the community between 1987 and 1992 (Poole 1995), coupled with Poole's unpublished resightings of these individuals in the intervening years, suggest a life-time site fidelity for at least some individuals (life-span is not precisely known for Gray's spinner dolphins but is likely around 20 to $25 \mathrm{yr}$ ). A similar level of site fidelity has been reported from intermittent resights data at Oahu, Hawaii (Marten \& Psarakos 1999), but to our knowledge, Moorea is the only location where individual spinner dolphins have been resighted regularly over such a long period of time.

Although our observations also indicate some level of social openness, notably to dolphins from Tahiti, overall the level of interchange appears to be low. We found no evidence of permanent immigration, while Poole (1995) recorded only 2 cases of long-term immigrants across the $5 \mathrm{yr}$ of his surveys. Contrary to the Midway Atoll (Karczmarski et al. 2005), Moorea is not geographically isolated from any other island, Tahiti being just $17 \mathrm{~km}$ distant (the closest island to Midway is the Kure Atoll, $96 \mathrm{~km}$ to the east). Despite this proximity, our photo-identification and genetic results clearly indicate that a distinct community of spinner dolphins use the near-shore waters of Tahiti. We note that interchanges with the neighbouring community also occur in the form of temporary 'visits', as recorded in August 2002.

\section{Demographic community trends in the Society Archipelago}

Compared to what is known at Moorea from photoidentification, demographic information from the other islands is incomplete. However, from similarities in habitat use, group size and behaviour among the different islands, it seems reasonable to assume that the general demographic pattern described here (i.e. a small and relatively closed community on an intra-generational time scale) also holds for the other spinner dolphin communities, at least in the Society Archipelago. This pattern of island fidelity is also supported by the resighting of similar DMIs on 2 consecutive years 
at Tahiti and Raiatea. Indeed, 4 of the 5 DMIs identified at Tahiti in 2003 were resighted in 2004, while 3 of the 4 DMIs identified at Raiatea in 2003 were resighted in 2004 (Table 1).

Based on contrasting results from the Big Island of Hawaii (Norris et al. 1994), Karczmarski et al. (2005) suggested that small population size and social stability at Midway Atoll are driven by habitat variation and geographic isolation. This does not seem entirely true in the Society Islands. Stable demography at Moorea (based on photo-identification data) and significant genetic structure in the archipelago (see below) indicate that small and closed communities can occur in groups of islands that are not geographically isolated. Therefore, benefits resulting from habitat fidelity (e.g. social interactions, local knowledge), or ecological constraints other than geographic isolation (e.g. competition for habitat), seem to influence the demographic closure of insular communities.

\section{Population genetic structure and sex-biased dispersal}

Although island fidelity is likely to represent the norm in the Society Archipelago, evolutionary history and current connectivity between communities would remain unknown without the support of molecular data. Our molecular analyses reveal a fine-scale genetic structure in these insular communities of spinner dolphins. Although recent population divergence could explain low levels of genetic differentiation, our demographic data suggest that for these islands, ongoing gene flow is more likely to be responsible for such a pattern.

A surprising result was the genetic isolation and low diversity at Tahiti. This difference was evident even when compared to the neighbouring community at Moorea, indicating low-level gene flow between the 2 island communities, particularly female gene flow (i.e. mtDNA). This differentiation with other island samples was also illustrated by a comparatively low level of mtDNA genetic diversity at Tahiti. Although this genetic pattern could be explained by a recent demographic bottleneck followed by population expansion (as suggested by a significant Fu's Fs), this scenario is not supported by the bottleneck tests based on microsatellites. An alternate explanation would be a fairly strict closure to immigration (at least concerning females) driven by social and/or demographic forces. We note that the southwest coastline of Tahiti (opposite side of the island from Moorea) was not surveyed during this study. Therefore, we cannot exclude the existence of another community of spinner dolphins within this unexplored area.
Although only a small number of samples were collected at Nuku Hiva ( $\mathrm{n}=8$ ), we found a high level of genetic differentiation between this community and those at all other islands. Unlike the differences among the Society Islands, the differentiation of Nuku Hiva is most likely due to the geographic isolation between the 2 archipelagos $(1500 \mathrm{~km})$. However, the absence of phylogeographic structure between samples and the finding of one common haplotype between both archipelagos suggest either a recent isolation or low levels of ongoing gene flow.

Overall, gene flow appeared to be biased toward males, showing agreement with the predominant mating system in mammals (Greenwood 1980) and that of other delphinid species (Escorza-Trevino \& Dizon 2000, Möller \& Beheregaray 2004). Although the degree of bias is difficult to judge, the greater effect apparent in the sex-specific $v A i c$, to the sex-specific $F_{\mathrm{ST}}$, suggests that dispersal rate is low overall (less than $10 \%$ per generation, Goudet et al. 2002). A trend in male-biased dispersal was also supported by the observation of 3 males at Raiatea (established by genotype matches) that were initially sampled at Huahine.

However, dispersal is not totally restricted to males, as 1 female was successively sampled at Moorea and Bora Bora. Female gene flow was indicated by numerous shared mtDNA haplotypes and low levels of mtDNA differentiation between some island samples. Taken together, our results suggest 2 distinct mechanisms of gene flow in insular communities of spinner dolphins: gene flow resulting from overlapping home ranges and temporary 'visits' (possibly biased toward males), and gene flow resulting from occasional longterm immigration, of females as well as males, perhaps travelling in groups. Males might also disperse but achieve little reproductive success as immigrants. Such demographic trends could explain our field observations and the genetic pattern of mitochondrial and nuclear DNA.

\section{Pelagic colonization or island metapopulation?}

A striking characteristic of our results was the high level of mitochondrial genetic diversity (as illustrated by estimates of $N_{\mathrm{ef}}$ ) in contrast to the relative demographic isolation of small communities. We note that $N_{\text {ef }}$ estimates are subject to considerable uncertainty due to the method used to estimate $\mu$ and $\theta$, and must be interpreted cautiously (Waples 2002). However, even lower values of the $95 \%$ confidence intervals still indicate very large $N_{\text {ef }}$.

Observed levels of genetic diversity could reflect the effect of founder events, due to recent colonization of insular habitats. In such case, the diversity would sim- 
ply be the signal of the historical polymorphisms contained in a large parental population, potentially from a pelagic source, such as the Eastern Tropical Pacific. Long-term effective population size $\left(N_{\mathrm{e}}\right)$ can indeed reflect, for a few generations at least, a population's pre-bottleneck history rather than its current demography (e.g. Storz et al. 2002). However, in our data, we found no indirect evidence for such a colonization scenario in the frequencies of mtDNA haplotypes or microsatellite alleles using various tests for a bottleneck. Furthermore, dedicated boat surveys (Gannier 2000) and aerial surveys (Poole 1995) in the inshore and offshore waters of the Society Archipelago found no evidence for the existence of an offshore population of spinner dolphins in this area. Thus, it appears unlikely that current connectivity with a large pelagic population can explain the high genetic diversity in spinner dolphins of the Society Islands.

Instead, we consider that current levels of mitochondrial diversity in insular communities of the Society Archipelago are more likely the result of a metapopulation dynamic. In the classical metapopulation model, the environment consists of spatially isolated patches of suitable habitat positioned within a continuum of unsuitable habitat that individuals can traverse but within which they cannot breed (Levins 1969). The demographic pattern we describe here and the significant genetic differences between these insular communities suggest that spinner dolphins from the Society Archipelago follow this model.

In a metapopulation dynamic, the observed discrepancy between the high level of genetic diversity and census size is not unexpected. Indeed, it has been shown that $N_{\mathrm{e}}$ often exceeds the instantaneous census number of populations that are subdivided into a network of socially defined breeding groups (e.g. Sugg et al. 1996). Moreover, with sufficient dispersal between patches, $N_{\mathrm{e}}$ of subpopulations can approach $N_{\mathrm{e}}$ of the whole metapopulation (Hedrick \& Gilpin 1997). Our results support this pattern, with $N_{\text {ef }}$ estimated for the Society Archipelago islands being comparable to $N_{\text {ef }}$ estimated for single islands.

We note that even under a metapopulation dynamic, our estimates of $N_{\text {ef }}$ are so large that they suggest an overall population that must extend beyond the boundaries of the Society Archipelago. Several evolutionary histories could explain this pattern: (1) spinner dolphins are commonly distributed throughout the insular habitats of the tropical and subtropical Pacific (South Pacific Whale Research Consortium [SPWRC] 2004), which include more than 20000 islands, more or less remote from one another. The extent of this habitat could thus support a very large metapopulation (following the model described here for the Society Archipelago) and would explain the current of high levels of genetic diversity. However, our results suggest that geographic distance can represent a limit to gene flow; or, (2) current gene flow occurs between insular spinner dolphins and large pelagic populations found in the ETP. The distributional limit of the whitebelly spinner dolphin is fairly close to the Marquesas Archipelago (Fig. 1a) and could represent a zone of interchange with the insular spinner dolphins of the Central and West Pacific. In this case, the metapopulation would follow a mainland-island model (Harrison 1991), where the mainland is represented by pelagic populations. In a worldwide study of spinner dolphin genetic diversity, Galver (2002) found no obvious phylogeographic structuring in mtDNA haplotypes, even between subspecies of spinner dolphins (although no samples from French Polynesia were available in this study). Current gene flow between subspecies is thus a possibility. Finally (3), Galver (2002) suggested a recent worldwide demographic expansion of spinner dolphins to explain a lack of phylogeographic structure. Such a global event could also have influenced the current genetic diversity found in our population, although such diversity could not persist in the small island communities without additional influences.

By combining a demographic approach with molecular tools, our study provides valuable insights into the structure and dynamics of insular spinner dolphin communities. We showed that these communities are based on a complex equilibrium between isolation and interchange. While social stability and site fidelity represent strong components, genetic diversity reveals that communities are still evolutionarily connected through gene flow. However, further studies covering a larger geographical scale are still needed to clarify the extent of the metapopulation and the influence of historical events as well as proximate social reproductive barriers on current patterns of genetic diversity. From a conservation perspective, the complex population dynamic described here shows that geographically isolated communities of insular spinner dolphins are likely to represent separate management units on an ecological time scale. Considering the regular use of inshore habitat by this species, we recommend a detailed assessment of the degree of connectivity (intra- and inter-generation) of communities that are particularly exposed to human activity in order to ensure proper management for their long-term viability and equilibrium of the metapopulation dynamic.

Acknowledgements. We thank E. Méchain, M. Ballesteros, R. Holler, V. Ducreux, Y. Ducreux, A. Legrand, E. Leprêtre, E. Curvat and the diving center of Nuku Hiva for field assistance; R. Galzin from the Centre de Recherches Insulaires et Observatoire de l'Environnement (CRIOBE) for his advice and technical support during fieldwork; and the SPWRC and the International Fund for Animal Welfare (IFAW) for support 
of collaborative research in the South Pacific. Research was conducted under permit from the French Polynesian government and the 'Direction de l'Environnement'. Skin biopsy samples were collected under Protocol AEC/02/2005/R334 approved by the University of Auckland Animal Ethics Committee. A PhD fellowship for M.O. and support for fieldwork and laboratory analysis was provided to C.S.B. by the New Zealand Marsden Fund. Funding for the purchase of the research boat was provided by Vista Press to M.M.P; other funding was provided to M.M.P. by the Englehard Foundation and by donations given through the National Oceanic Society. This paper benefited from comments by V. Lukoschek, M. Dalebout, R. LeDuc and 2 anonymous reviewers.

\section{LITERATURE CITED}

Amos B, Schlötterer C, Tautz D (1993) Social structure of pilot whales revealed by analytical DNA profiling. Science 30: 670-672

Aris-Brosou S, Excoffier L (1996) The impact of population expansion and mutation rate heterogeneity on DNA sequence polymorphism. Mol Biol Evol 13:494-504

Arnason U, Gullberg A, Janke A (2004) Mitogenomic analyses provide new insights into cetacean origin and evolution. Gene 333:27-34

Arnborn T (1987) Individual identification of sperm whales. Rep Int Whal Comm 37:201-204

Baker CS, Perry A, Bannister JL, Weinrich MT and 10 others (1993) Abundant mitochondrial DNA variation and worldwide population structure in humpback whales. Proc Natl Acad Sci USA 90:8239-8243

Baker CS, Slade RW, Bannister JL, Abernethy RB and 7 others (1994) Hierarchical structure of mitochondrial DNA gene flow among humpback whales, Megaptera novaeangliae, world-wide. Mol Ecol 3:313-327

Bandelt H, Forster P, Rohl A (1999) Median-joining networks for inferring intraspecific phylogenies. Mol Biol Evol 16: $37-48$

Barnes LG (1985) Evolution, taxonomy and anti-tropical distributions of the porpoises (Phocoenidae, Mammalia). Mar Mamm Sci 1:149-165

Bérubé M, Jørgensen H, McEwing R, Palsbøll PJ (2000) Polymorphic di-nucleotide microsatellite loci isolated from the humpback whale, Megaptera novaeangliae. Mol Ecol 9: 2155-2234

Bowden DC, Kufeld RC (1995) Generalized mark-resight population size estimation applied to Colorado moose. J Wildl Manage 59:840-851

Caldwell M, Gaines M, Hughes CR (2002) Eight polymorphic microsatellite loci for bottlenose dolphin and other cetacean species. Mol Ecol Notes 2:393-395

Caughley G (1977) Analysis of vertebrate populations. Wiley, London

Cornuet JM, Luikart G (1996) Description and power analysis of two tests for detecting recent population bottlenecks from allele frequency data. Genetics 144:2001-2014

Dalebout ML, Van Helden A, Van Waerebeek K, Baker CS (1998) Molecular genetic identification of southern hemisphere beaked whales (Cetacea: Ziphiidae). Mol Ecol 7: 687-695

Dalebout ML, Robertson KM, Frantzis A, Engelhaupt D, Mignucci-Giannoni AA, Rosario-Delestre RJ, Baker CS (2005) Worldwide structure of mtDNA diversity among Cuvier's beaked whales (Ziphius cavirostris): implications for threatened populations. Mol Ecol 14:3353-3371

Escorza-Trevino S, Dizon AE (2000) Phylogeography, intraspecific structure and sex-biased dispersal of Dall's porpoise, Phocoenoides dalli, revealed by mitochondrial and microsatellite DNA analyses. Mol Ecol 9:1049-1060

Excoffier L, Smouse PE, Quattro JM (1992) Analysis of molecular variance inferred from metric distances among DNA haplotypes: application to human mitochondrial DNA restriction data. Genetics 131:479-491

Excoffier L, Laval LG, Schneider S (2005) Arlequin ver. 3.0: an integrated software package for population genetics data analysis. Evol Biol Online 1:47-50

Fu XY (1997) Statistical tests of neutrality of mutations against population growth, hitchhiking and background selection. Genetics 147:915-925

Galver L (2002) The molecular ecology of spinner dolphins, Stenella longirostris: genetic diversity and population structure. PhD thesis, University of California, San Diego, CA

Gannier A (2000) Distribution of cetaceans off the Society Islands (French Polynesia) as obtained from dedicated survey. Aquat Mamm 26:111-126

Garza JC, Williamson EG (2001) Detection of reduction in population size using data from microsatellite loci. Mol Ecol 10:305-318

Gilson A, Syvanen M, Levine K, Banks J (1998) Deer gender determination by polymerase chain reaction: validation study and application to tissues, bloodstains, and hair forensic samples from California. Calif Fish Game 84: 159-169

Goldstein DB, Schlötterer C (1999) Microsatellites: evolution and applications. Oxford University Press, Oxford

Goudet J (2001) FSTAT, a program to estimate and test gene diversities and fixation indices (version 2.9.3). www2.unil.ch/popgen/softwares/fstat.htm

Goudet J, Perrin N, Waser P (2002) Tests for sex-biased dispersal using bi-parentally inherited genetic markers. Mol Ecol 11:1103-1114

Greenwood PJ (1980) Mating systems, philopatry and dispersal in birds and mammals. Anim Behav 28:1140-1162

Harrison S (1991) Local extinction in a metapopulation context: an empirical evaluation. Biol J Linn Soc 42:73-88

Hedrick PW, Gilpin ME (1997) Genetic effective size of a metapopulation. In: Hanski I, Gilpin ME (eds) Metapopulation biology: ecology, genetics, and evolution. Academic Press, San Diego, CA, p 165-181

Hoelzel AR, Potter CW, Best PB (1998) Genetic differentiation between parapatric 'nearshore' and 'offshore' populations of the bottlenose dolphin. Proc R Soc Lond B 265: $1177-1183$

Hudson RR (1990) Gene genealogies and the coalescent process. In: Futuyama F, Antonovics JD (eds) Oxford surveys in evolutionary biology, Vol 7. Oxford University Press, New York, p 1-44

Karczmarski L, Würsig B, Gailey G, Larson KW, Vanderlip C (2005) Spinner dolphins in a remote Hawaiian atoll: social grouping and population structure. Behav Ecol 16: 675-685

Krützen M, Valsecchi E, Connor RC, Sherwin WB (2001) Characterization of microsatellite loci in Tursiops aduncus. Mol Ecol Notes 1:170-172

Krützen M, Barré LM, Möller LM, Heithaus MR, Simmer C, Sherwin WB (2002) A biopsy system for small cetaceans: darting success and wound healing in Tursiops spp. Mar Mamm Sci 18:863-878

Kuhner MK (2006) LAMARC 2.0: maximum likelihood and Bayesian estimation of population parameters. Bioinformatics 22:768-770

Lammers MO (2004) Occurrence and behavior of Hawaiian 
spinner dolphins (Stenella longirostris) along Oahu's leeward and south shores. Aquat Mamm 30:237-250

Lande R (1988) Genetics and demography in biological conservation. Science 241:1455-1460

Levins R (1969) Evolution in changing environments: some theoretical explorations. Princeton University Press, Princeton, NJ

Luikart GH, Allendorf FW, Cornuet JM, Sherwin WB (1998) Distortion of allele frequency distributions provides a test for recent population bottlenecks. J Hered 89:238-247

Maddison DR, Maddison WP (2000) MacClade 4: analysis of phylogeny and character evolution. Sinauer Associates, Sunderland, MA

Marshall TC, Slate J, Kruuk LEB, Pemberton JM (1998) Statistical confidence for likelihood-based paternity inference in natural populations. Mol Ecol 7:639-655

Marten K, Psarakos S (1999) Long-term site fidelity and possible long-term associations of wild spinner dolphins (Stenella longirostris) seen off Oahu, Hawaii. Mar Mamm Sci 15:1329-1336

Miller CR, Joyce P, Waits LP (2005) A new method for estimating the size of small populations from genetic mark-recapture data. Mol Ecol 14:1991-2005

Möller LM, Beheregaray LB (2004) Genetic evidence for sexbiased dispersal in resident bottlenose dolphins (Tursiops aduncus). Mol Ecol 13:1607-1612

Norris KS, Würsig B, Wells RS, Würsig M (1994) The Hawaiian spinner dolphin. University of California Press, Berkeley, CA

Palsbøll PJ, Bérubé M, Larsen AH, Jørgensen H (1997) Primers for the amplification of tri- and tetramer microsatellite loci in baleen whales. Mol Ecol 6:893-895

Perrin WF, Gilpatrick JWJ (1994) Spinner dolphin Stenella longirostris (Gray, 1828). In: Ridgway SH, Harrison R (eds) Handbook of marine mammals, Vol 5. Academic Press, London, p 99-128

Peakall R, Smouse P (2006) GENALEX 6: genetic analysis in Excel. Population genetic software for teaching and research. Mol Ecol Notes 6:288-295

Perrin WF, Henderson JR (1984) Growth and reproductive rates in two populations of spinner dolphins, Stenella longirostris, with different histories of exploitation. Rep Int Whal Comm Spec Issue 6:417-430

Perrin WF, Mesnick SL (2003) Sexual ecology of the spinner dolphin, Stenella longirostris: geographic variation in mating system. Mar Mamm Sci 19:462-483

Perrin WF, Dolar LL, Robineau D (1999) Spinner dolphins (Stenella longirostris) of the Western Pacific and Southeast Asia: pelagic and shallow-water forms. Mar Mamm Sci 15: 1029-1053

Poole MM (1995) Aspects of the behavioral ecology of spinner dolphins (Stenella longirostris) in the nearshore waters of

Editorial responsibility: Otto Kinne (Editor-in-Chief), Oldendorf/Luhe, Germany
Mo'orea, French Polynesia. PhD thesis, University of California, Santa Cruz, CA

Posada D, Crandall KA (1998) MODELTEST: testing the model of DNA substitution. Bioinformatics 14:817-818

Rice WR (1989) Analyzing tables of statistical tests. Evolution 43:223-225

Rosel PE, France SC, Wang JY, Kocher TD (1999) Genetic structure of harbour porpoise Phocoena phocoena populations in the northwest Atlantic based on mitochondrial and nuclear markers. Mol Ecol 8:S41-S54

Sambrook J, Fritsch EF, Maniatis T (1989) Molecular cloning: a laboratory manual. Cold Spring Harbor Laboratory Press, Cold Spring Harbor, NY

Silva Jr JM, Silva FJL, Sazima I (2005) Rest, nurture, sex, release, and play: diurnal underwater behaviour of the spinner dolphin at Fernando de Noronha Archipelago, SW Atlantic. J Ichthyol Aquat Biol 9:161-176

South Pacific Whale Research Consortium (SPWRC) (2004) Report of the annual meeting of the South Pacific Whale Research Consortium: 2-6 April 2004, Byron Bay, NSW, Australia. Report to the scientific committee of the International Whaling Commission SC/55/SH7, Cambridge

Storz JF, Ramakrishnan U, Alberts SC (2002) Genetic effective size of a wild primate population: influence of current and historical demography. Evolution 56:817-829

Sugg DW, Chesser RK, Dobson FS, Hoogland. JL (1996) Population genetics meets behavioral ecology. Trends Ecol Evol 11:338-342

Tajima F (1989a) The effect of change in population size on DNA polymorphism. Genetics 123:597-601

Tajima F (1989b) Statistical method for testing the neutral mutation hypothesis by DNA polymorphism. Genetics 123:585-595

Valsecchi E, Amos W (1996) Microsatellite markers for the study of cetacean populations. Mol Ecol 5:151-156

Wade PR, Gerrodette T (1993) Estimates of cetacean abundance and distribution in the eastern tropical Pacific. Rep Int Whal Comm 43:477-493

Waples RS (2002) Definition and estimation of effective population size in the conservation of endangered species. In: Beissinger SR, McCullough DR (eds) Population viability analysis. The University of Chicago Press, Chicago, IL

Wells RS (2003) Dolphin social complexity: lessons from longterm study and life history. In: de Waal FBM, Tyack PL (eds) Animal social complexity: intelligence, culture, and individualized societies. Harvard University Press, Cambridge, MA

White GC (1996a) NOREMARK: population estimation from mark-resight surveys. Wildl Soc Bull 24:50-52

White GC (1996b) Program NOREMARK software reference manual. Department of Fisheries and Wildlife. Colorado State University, Fort Collins, CO

Submitted: August 16, 2006; Accepted: October 13, 2006 Proofs received from author(s): April 19, 2007 